\title{
INHIBITORY POTENTIAL OF POLYHYDROXYLATED FULLERENES AGAINST PROTEIN TYROSINE PHOSPHATASE 1B
}

\author{
O. L. KOBZAR, V. V. TRUSH, V. Yu. TANCHUK, A. I. VOVK \\ Institute of Bioorganic Chemistry and Petrochemistry, \\ National Academy of Sciences of Ukraine, Kyiv; \\ e-mail:vovk@bpci.kiev.ua
}

Inhibition of PTP1B by polyhydroxylated fullerenes was studied in silico and in vitro. The enzyme kinetics in the presence of polyhydroxy small gap fullerenes showed that reciprocal value of maximum velocity non-linearly increases with increasing the inhibitor concentration. Analysis of the dose-dependent curve of PTP1B inhibition suggests an apparent positive cooperativity with involvement of at least two binding sites for the hydroxylated fullerene cages. Molecular docking calculations indicated that highly hydroxylated fullerene $C_{60}$ may occupy the active site and additional allosteric binding site with similar affinity. In silico analysis of a number of fullerenols with 6, 12, 18, 24, 30, and 36 hydroxyl groups showed that the inhibitory activity may depend on the degree of hydroxylation of the nanoparticles surface. These data provide some understanding of the mechanisms of inhibitory action of fullerenols on activity of protein tyrosine phosphatases.

K e y words: protein tyrosine phosphatase, PTP1B, fullerenes, fullerenols.

$\mathrm{P}$ olyhydroxylated fullerene derivatives (fullerenols) are characterized by promising biological properties including immunomodulating, anticancer [1-3] and antimetastatic activities [4]. The ability of fullerenols to neutralize free radicals is associated with their possible use as antioxidants and radioprotective agents in living cells [5,6]. In addition, fullerenols are able to inhibit the activity of enzymes such as P450-dependent monooxygenase, $\mathrm{Mg}^{2+}$-ATPase [7], M-MuLV reverse transcriptase [8], lysozyme [9], and monoamine oxidase B [10].

We have previously reported that fullerenol and some other fullerene derivatives can also be effective as inhibitors of human protein tyrosine phosphatases (EC 3.1.3.48) [11-13]. These regulatory enzymes catalyze dephosphorylation of tyrosine residues in signaling proteins, and abnormal changes in their activities may lead to development of serious diseases [14]. Some receptor and non-receptor protein tyrosine phosphatases are involved in the regulation of insulin signaling. Among them, protein tyrosine phosphatase 1B (PTP1B) provides dephosphorylation of the insulin receptor tyrosine residues contributing to type 2 diabetes risk [15, 16]. Negative role of PTP1B in obesity is associated with the blocking of transduction signal from the leptin hormone via dephosphorylation of Jak2 [17]. Furthermore, the en- zyme may act as a promoter or suppressor of tumor development [18].

In this context, search for effective PTP1B inhibitors is essential for drug design [19], and the polyhydroxylated fullerenes can be considered as potential therapeutic agents exhibiting significantly lower toxicity in comparison with the unmodified ones [20-22]. The aim of the present report was to elucidate some characteristics of polyhydroxy small gap fullerenes as inhibitors of PTP1B in vitro. In addition, molecular docking was performed to predict the inhibitory potential of the nanoparticles with different number of hydroxyl groups against PTP1B as a favorable target.

\section{Materials and Methods}

PTP1B, $p$-nitrophenyl phosphate ( $p$-NPP), 4-methylumbelliferyl phosphate disodium salt (4-MUP), ethylenediamine tetraacetate disodium salt (EDTA) and dithiotreitol (DTT) were purchased from Sigma-Aldrich. Preparation of polyhydroxy small gap fullerenes (Sigma-Aldrich) was used without additional purification as a representative fullerenol with about thirty oxy functionalities per one fullerene core of the common formula $\mathrm{C}_{120} \mathrm{O}_{30}(\mathrm{OH})_{30} \cdot 30 \mathrm{H}_{2} \mathrm{O} \cdot 25 \mathrm{Na}^{+}$. 
For studying the inhibition of PTP1B in vitro, a typical reaction mixture consisted of $0.05 \mathrm{M}$ bisTris buffer (pH 7.2), $100 \mathrm{mM} \mathrm{NaCl}, 3 \mathrm{mM}$ EDTA, $1 \mathrm{mM}$ DTT, $1 \%$ dimethyl sulphoxide, recombinant $\mathrm{PTP}_{1-436}$ (1-436 amino acid residues) and $p$-NPP as an artificial substrate. In some of kinetic experiments, fluorogenic substrate 4-MUP was employed to analyze the inhibition of PTP1B ${ }_{1-322}$. The mixture was incubated during $5 \mathrm{~min}$ at $37^{\circ} \mathrm{C}$. The reaction was started by adding the enzyme (in the case of $p$-NPP) or substrate (in the case of 4-MUP). The enzymatic hydrolysis of $p$-NPP was monitored spectrophotometrically at $410 \mathrm{~nm}$ by watching the accumulation of $p$-nitrophenol. The rate of 4-MUP hydrolysis was observed due to increasing concentrations of fluorescent product, 4-methylumbelliferone (excitation wavelength and emission wavelength were 360 and $450 \mathrm{~nm}$, respectively). Hill slope was calculated using four-parameter equation from the dose-dependent inhibition curve and shown as the mean value \pm standart error. Apparent $\mathrm{IC}_{50}$ value was the inhibitor concentration that inhibits the enzyme activity by $50 \%$ and is given as the mean value \pm standart deviation. Kinetic data of $p$-NPP and 4-MUP enzymatic transformations were analyzed using Lineweaver-Burk double reciprocal plots. The kinetic and statistical calculations were carried out using MS Excel software.

Computer-simulation studies of PTP1B (structures with PDB identification codes 1NL9 and 2CM8) were performed by Autodock Vina [23]. Additional calculations with Autodock 4.2 showed the similar positions of the hydroxylated fullerenes on the surface of PTP1B. Energetically favorable structures $[24,25]$ of the fullerene ligands were optimized by Avogadro software [26] using the MMFF94s force field.

\section{Results and Discussion}

Polyhydroxy small gap fullerenes with $\mathrm{OH}$ and ONa groups covalently attached to the nanoscale carbon core were used as a water-soluble polyhydroxy fullerene example [27] to inhibit PTP1B in vitro. The previous studies [12] showed that the polyhydroxylated fullerenes can display strong inhibitory effects towards this enzyme. In this paper, the two artificial substrates, $p$-NPP and 4-MUP, were applied to elucidate the kinetic characteristics of the inhibition.

Progress curves of $p$-NPP hydrolysis catalyzed by PTP1B in the presence of polyhydroxylated fullerenes (Fig. 1) showed a time-dependent decrease

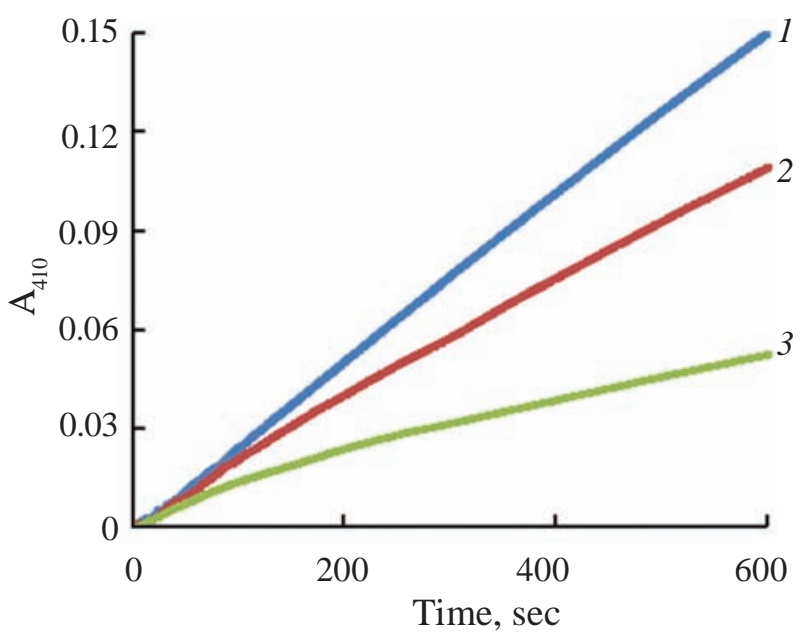

Fig. 1. The hydrolysis curves of $p-N P P$ by the protein tyrosine phosphatase $1 B$ in absence (1) and in the presence of polyhydroxylated fullerenes at concentrations of 0.0722 (2) and $0.271 \mu \mathrm{g} / \mathrm{ml}$ (3)

in the reaction rate. Reaching a steady-state velocity was observed after about the first five minutes of $p$-nitrophenol accumulation. Taking into account the slow-binding inhibition, the steady-state kinetics was used to analyze the enzyme inhibition.

The dose-dependent curve of PTP1B suppression by the polyhydroxylated fullerenes is presented in Fig. 2. Under assay conditions, the fullerenols have a high inhibitory potential with activity at concentration from 0.01 to $1 \mu \mathrm{g} / \mathrm{ml}$ (based on representative fullerene derivative $\mathrm{C}_{60}(\mathrm{OH})_{30}$, molar concentrations of the inhibitor may be given in range from 5 to $500 \mathrm{nM}$ ). The apparent $\mathrm{IC}_{50}$ value was $0.114 \pm 0.033 \mu \mathrm{g} / \mathrm{ml}$ that is in agreement with

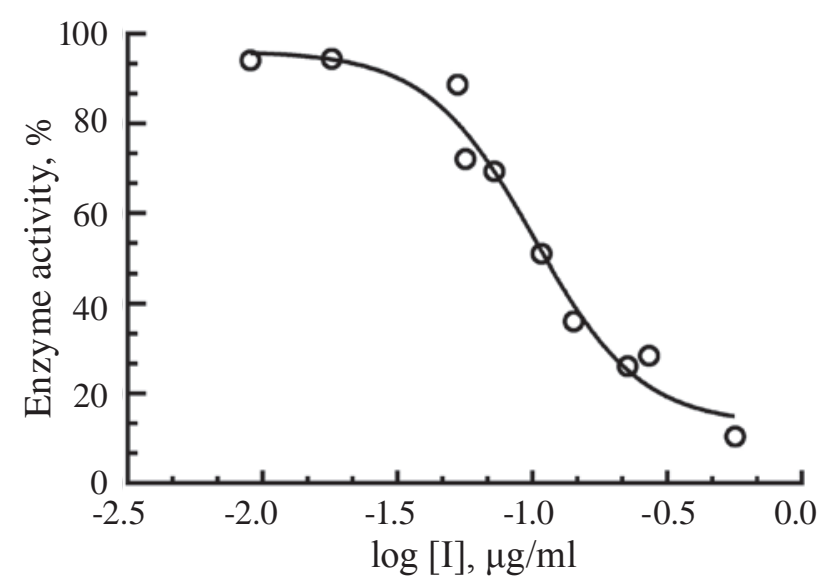

Fig. 2. Dose-dependent inhibition curve of PTP1B by polyhydroxylated fullerenes. $p$-NPP was used as a substrate 

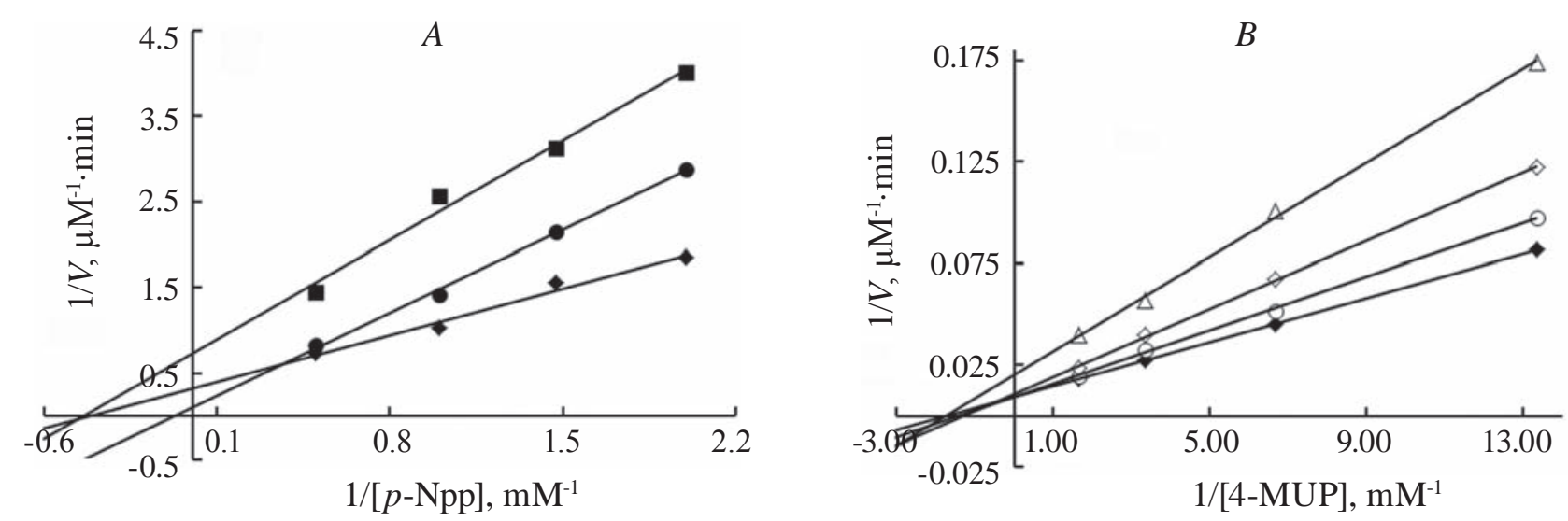

Fig. 3. Lineweaver-Burk plots of PTP1B inhibition by polyhydroxylated fullerenes. $p$-NPP (A) or 4-MUP (B) were used as a substrate. The inhibitor concentration were $0(\bullet), 0.036 \mu \mathrm{g} / \mathrm{ml}(\mathrm{O}), 0.054 \mu \mathrm{g} / \mathrm{ml}(\bullet), 0.072 \mu \mathrm{g} / \mathrm{ml}$ $(\diamond), 0.108 \mu \mathrm{g} / \mathrm{ml}(\mathbf{\square})$, and $0.144 \mu \mathrm{g} / \mathrm{ml}(\Delta)$

previously reported data [12]. The Hill coefficient value was found to be $2.20 \pm 0.51$. This suggests an apparent positive cooperative effect with involvement of at least two binding sites of PTP1B for the hydroxylated fullerene cages.

The plots of the steady-state velocity against the concentration of the substrate $(1 / V$ versus $1 /[\mathrm{S}])$ were linear (Fig. 3, $A$, the values of $\mathrm{r}^{2}$ are 0.98-0.99), however, the graphical analysis does not allow identifying the type of inhibition.

Similar results were obtained with 4-MUP as a substrate (Fig. 3, $B$, the values of $r^{2}$ are 0.99 ). The observed kinetic effects of the polyhydroxylated fullerenes at concentration $0.1 \mu \mathrm{g} / \mathrm{ml}$ may be correlated with self-assembly of the nanoparticles in the aqueous phase $[28,29]$. At the same time, analysis of

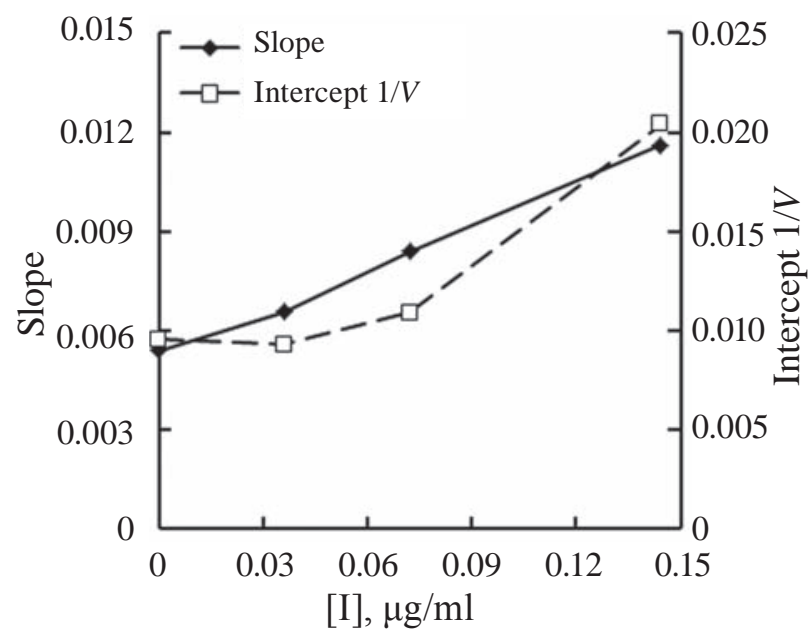

Fig. 4. The dependence of the slope and intercept (data from Fig. 3, B) on the inhibitor concentration

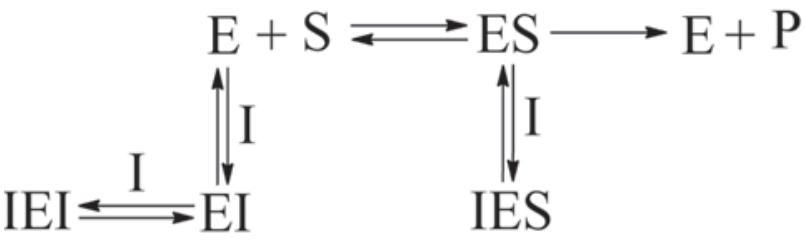

Scheme. Possible kinetic scheme of PTP1B inhibition by polyhydroxylated fullerenes

the secondary replots of slope and intercept versus the inhibitor concentration (Fig. 4) shows that value of the intercept $\left(1 / V_{\max }\right)$ increases non-linearly with increasing the inhibitor concentration but dependence of the slope on the inhibitor concentration is linear, which can be characteristic of S-linear I-parabolic mechanism of inhibition [30, 31]. The parabolic character of the dependence of $1 / V_{\max }$ on the inhibitor concentration is in accordance with interaction of fullerenol molecules with two binding sites of PTP1B. According to this suggestion, polyhydroxylated fullerenes interact with the enzyme to form EI, IEI, and IES inactive complexes (Scheme).

Optimization of ligand structures shows that attachment of hydroxyl groups to $\mathrm{C}_{60}$ leads to increase of molecular volume of the inhibitor, reduces aromaticity and consequently results in a distorted fullerene cage [24, 25]. Docking modeling of enzyme-inhibitor complexes (PDB code 1NL9) indicated that two wide cavities on PTP1B surface that are comparable to the size of the molecule of $\mathrm{C}_{60}(\mathrm{OH})_{30}$ can be formed by the active site region and allosteric inhibitor binding site (Fig. 5). Docking binding energies were calculated to be $-8.2 \mathrm{kcal} / \mathrm{mol}$ and $-7.7 \mathrm{kcal} /$ 
mol, respectively. Location of the inhibitor molecule in the active site is characterized by the presence of several hydrogen bonds and electrostatic interactions with Asp48, Glu115, Lys116, Lys120, Asp181, Ala217, Ser216, Gly220, Arg221, and Gln266 (Fig. 5, A). Additional forces that stabilize the enzyme-inhibitor complex are $\pi-\pi$ and $\pi$-cationic interaction with Tyr46 and Lys120, respectively. Distance to catalytically important Cys215 is approximately of $3.72 \AA$. However, the molecule of the hydroxylated fullerene can not occupy the active site of PTP1B with closed WPD-loop (PDB code 2CM8). In this case (as well as in case of PTP1B with open WPDloop), the fullerenol may be located at allosteric site at the distance of about $20 \AA$ from the catalytically important Cys215 [32]. The molecule of $\mathrm{C}_{60}(\mathrm{OH})_{30}$ occupies the region formed by helices $\alpha 3, \alpha 4, \alpha 6, \alpha 7$, and S-loop (Fig. 5, $B$ ) that are involved in conformational changes of PTP1B [32-34]. The inhibitor forms $\mathrm{H}$-bonds and electrostatic interaction with Arg79,
Arg199, Glu200, Gly202, Ser205, Glu207, Asp236, and $\mathrm{Gln} 288$.

The results of this docking revealed molecular fragments of representative hydroxylated fullerene $\mathrm{C}_{60}$ that are responsible for the interaction with the PTP1B. It should be noted that polyhydroxy small gap fullerene product is heterogeneous and rich in giant fullerenes larger than $\mathrm{C}_{60}$. Hence their complexes with the enzyme also may be suggested including, for example, the interaction with dimeric fullerene derivatives.

Molecular docking simulations of polyhydroxylated fullerene derivatives $\mathrm{C}_{60}(\mathrm{OH})_{6}, \mathrm{C}_{60}(\mathrm{OH})_{12}$, $\mathrm{C}_{60}(\mathrm{OH})_{18}, \mathrm{C}_{60}(\mathrm{OH})_{24}, \mathrm{C}_{60}(\mathrm{OH})_{30}, \mathrm{C}_{60}(\mathrm{OH})_{36}$ as inhibitors of PTP1B (Fig. 6) showed that the inhibitory potential of these compounds depends on degree of hydroxylation of the fullerene. The efficiency of the inhibitors decreases with increasing the number of hydroxyl groups and remains almost stable in case of the fullerenols containing more than 18

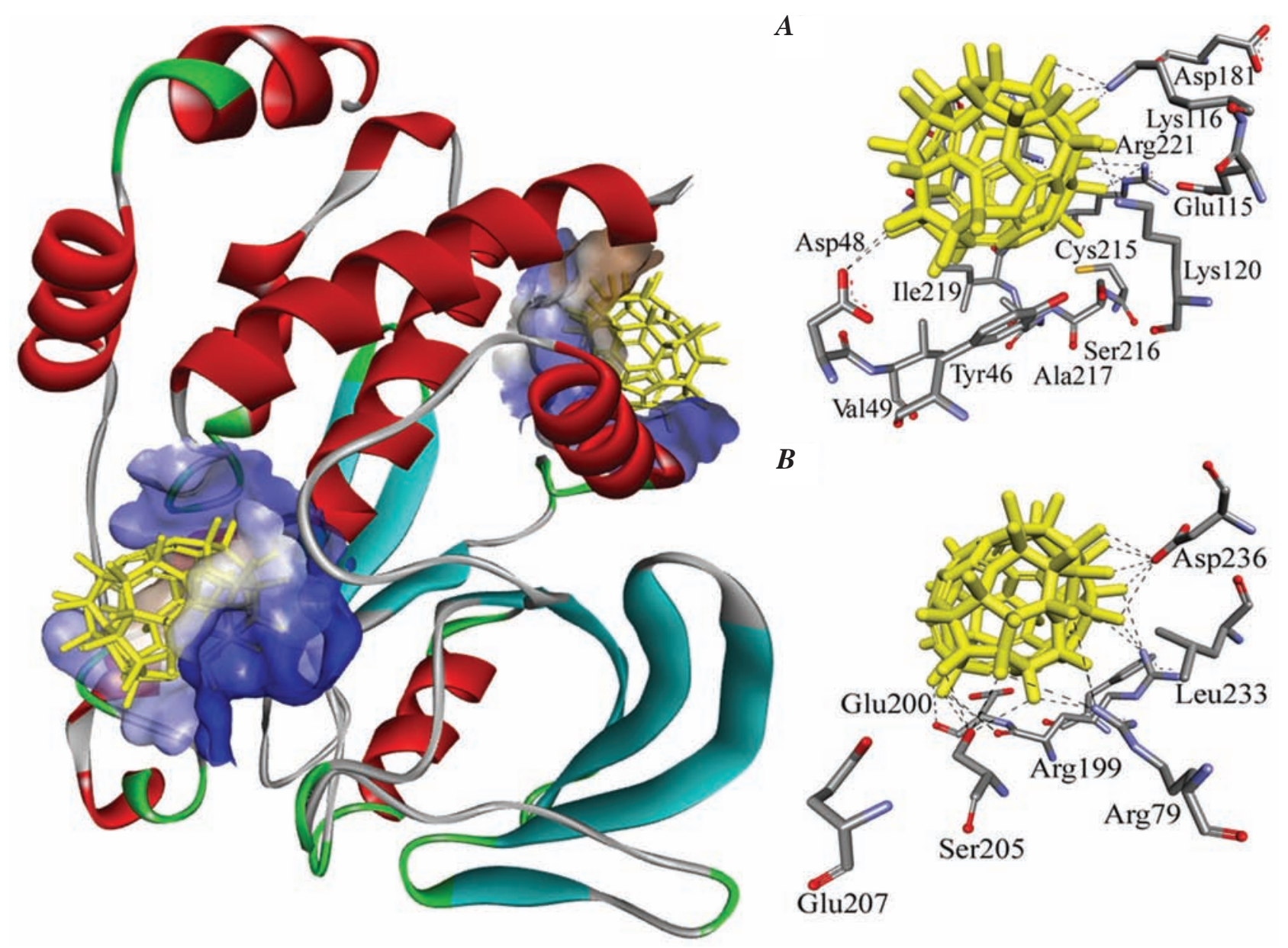

Fig. 5. Predicted binding modes of polyhydroxylated fullerene $C_{60}(\mathrm{OH})_{30}$ at the active site (A) and allosteric inhibitor binding site (B) of PTPIB with open WPD-loop (PDB identification code 1NL9) 


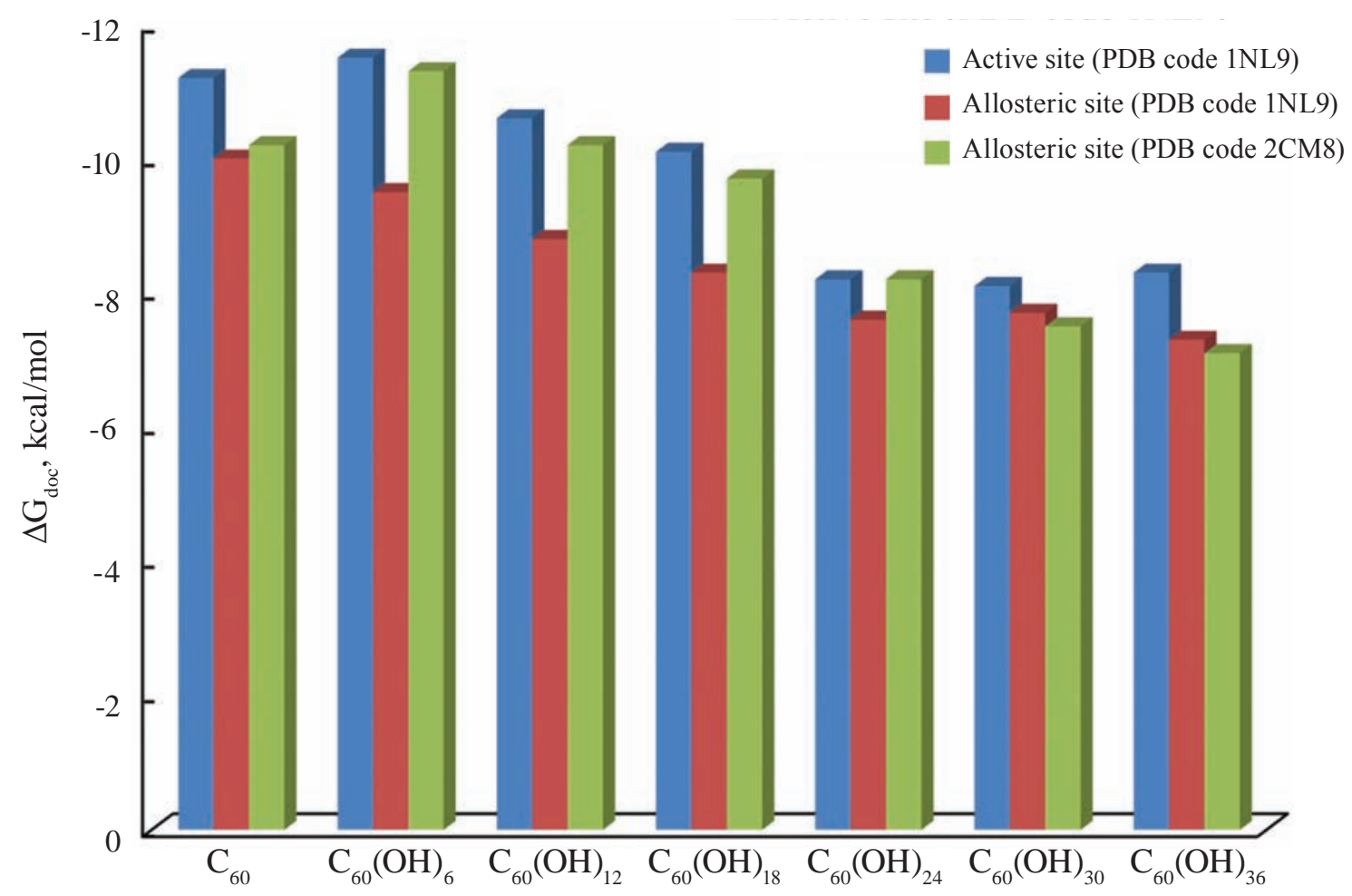

Fig. 6. Molecular docking energies of various polyhydroxylated fullerene derivatives bound to the PTP1B active site (PDB code 1NL9) and allosteric site (PDB codes 1NL9 and 2CM8)

$\mathrm{OH}$ groups. More hydrophilic nanoparticles bind to active and allosteric sites with approximately equal binding energies. In contrast, the fullerene derivatives with a lower degree of hydroxylation form more stable enzyme-inhibitor complexes interacting with hydrophobic residues at the active site of PTP1B. This is consistent with the fact that pyrrolidino[60]fullerene tris-carboxylic acid inhibits the activity of PTP1B in a competitive manner [12], whereas the polyhydroxylated fullerenes show the other inhibition types. It should also be noted that some of low functionalized fullerene derivatives exhibited selective inhibition of receptor-type protein tyrosine phosphatase CD45 (in contrary to PTP1B) which may be explained by significant hydrophobicity of CD45 surface [12, 13].

In conclusion, the results of kinetic studies showed that polyhydroxylated fullerenes may inhibit activity of PTP1B with positive cooperativity. Computer docking simulation indicated that $\mathrm{C}_{60}(\mathrm{OH})_{30}$ particles occupy the substrate binding site and allosteric inhibitor binding site of the enzyme with similar docking energies. The inhibition of PTP1B may depend on the degree of fullerene surface hydroxylation. These data provide some basis for understanding the mechanisms of inhibitory action of fullerenols on activity of PTP1B and other protein tyrosine phosphatases.

\section{ІНГІБУВАЛЬНА ЗДАТНІСТЬ ПОЛІГІДРОКСИЛЬОВАНИХ ФУЛЕРЕНІВ СТОСОВНО ПРОТЕЇНТИРОЗИНФОСФАТАЗИ 1В}
О. Л. Кобзар, В. В. Труи, В. Ю. Танчук, A. I. Вовк
Інститут біоорганічної хімії та нафтохімії НАН України, Київ; e-mail:vovk@bpci.kiev.ua

In silico та in vitro досліджено інгібування активності РТР1В полігідроксильованими фулеренами. Результати кінетичних досліджень ензиматичних реакцій за наявності полігідроксильованих фулеренів демонстрували нелінійне зростання оберненого значення уявної максимальної швидкості реакції з підвищенням концентрації інгібітора. Аналіз дозозалежної кривої припускає позитивну кооперативність iз залученням щонайменше двох сайтів зв'язування для полігідроксильованих фулеренових фрагментів. Комп'ютерні розрахунки 
показали, що полігідроксильовані фулерени $\mathrm{C}_{60}(\mathrm{OH})_{24-36}$ характеризуються приблизно однаковими значеннями енергії докінгу у разі взаємодії як 3 активним, так і $з$ алостеричним сайтами зв'язування. Аналіз результатів молекулярного докінгу ряду фулеренолів $36,12,18$, 24, 30 і 36 ОН-групами свідчить, що інгібуючий вплив залежить від ступеня гідроксилювання поверхні наночастинок. Ці дані є важливими для з'ясування механізмів інгібування активності протеїнтирозинфосфатаз фулеренолами.

К л ю чо в і с ло в а: протеїнтирозинфосфатази, РТР1В, фулерени, фулереноли.

\section{ИНГИБИРУЮЩАЯ СПОСОБНОСТЬ ПОЛИГИДРОКСИЛИРОВАННЫХ ФУЛЛЕРЕНОВ ПО ОТНОШЕНИЮ К ПРОТЕИНТИРОЗИНФОСФАТАЗЕ 1В}

\author{
А. Л. Кобзарь, В. В. Труи, В. Ю. Танчук, \\ А. И. Вовк
}

Институт биоорганической химии и нефтехимии НАН Украины, Киев; e-mail: vovk@bpci.kiev.ua

In silico и in vitro исследовано ингибирование активности РТР1В полигидроксилированными фуллеренами. Результаты кинетических исследований энзиматических реакций в присутствии полигидроксилированных фуллеренов демонстрировали нелинейный рост обратного значения кажущейся максимальной скорости реакции при повышении концентрации ингибитора. Анализ дозозависимой кривой предполагает положительную кооперативность с вовлечением по меньшей мере двух сайтов для связывания полигидроксилированных фуллереновых фрагментов. Компьютерные расчеты показали, что полигидроксилированные фуллерены $\mathrm{C}_{60}(\mathrm{OH})_{24-36}$ характеризуются примерно одинаковыми значениями энергии докинга при взаимодействии как с активным, так и с аллостерическим сайтами связывания. Анализ результатов молекулярного докинга ряда фуллеренолов с 6, $12,18,24,30$ и 36 ОН-группами свидетельствует, что ингибирующее влияние зависит от степени гидроксилирования поверхности наночастиц. Эти данные являются важными для понимания механизмов ингибирования активности протеинтирозинфосфатаз фуллеренолами.
Кл юче вы е слов а: протеинтирозинфосфатазы, РТР1В, фуллерены, фуллеренолы.

\section{References}

1. Zhu J., Ji Z., Wang J., Sun R., Zhang X., Gao Y., Sun H., Liu Y., Wang Z., Li A., Ma J., Wang T., Jia G., Gu Y. Tumor-inhibitory effect and immunomodulatory activity of fullerol $\mathrm{C}_{60}(\mathrm{OH})_{\mathrm{x}}$. Small. 2008;4(8):1168-1175.

2. Liu Y., Jiao F., Qiu Y., Li W., Qu Y., Tian Ch., Li Y., Bai R., Lao F., Zhao Y., Chai Z., Chen C. Immunostimulatory properties and enhanced TNF- $\alpha$ mediated cellular immunity for tumor therapy by $\mathrm{C}_{60}(\mathrm{OH})_{20}$ nanoparticles. Nanotechnology. 2009;20(41):415102.

3. Kojic V., Jakimov D., Bogdanovic G., Dordevic A. Effects of fullerenol $\mathrm{C}_{60}(\mathrm{OH})_{24}$ on cytotoxicity induced by antitumor drugs on human breast carcinoma cell lines. Mater. Sci. Forum. 2005;494:543-548.

4. Jiao F., Liu Y., Qu Y., Li W., Zhou G., Ge C., Li Y., Sun B., Chen Ch. Studies on anti-tumor and antimetastatic activities of fullerenol in a mouse breast cancer model. Carbon. 2010;48(8):22312243.

5. Trajkovic S., Dobric S., Jacevic V., DragojevicSimic V., Milovanovic Z., Dordevic A. Tissueprotective effects of fullerenol $\mathrm{C}_{60}(\mathrm{OH})_{24}$ and amifostine in irradiated rats. Colloids Surf. B. Biointerfaces. 2007;58(1):39-43.

6. Bogdanovic V., Stankov K., Icevic I., Zikic D., Nikolic A., Solajic S., Djordjevic A., Bodanovic G. Fullerenol $\mathrm{C}_{60}(\mathrm{OH})_{24}$ effects on antioxidative enzymes activity in irradiated human erythroleukemia cell line. Radiat. Res. 2008;49(3):321-327.

7. Ueng T.-H., Kang J.-J., Wang H.-H., Cheng Y. W., Chiang L. Y. Suppression of microsomal cytochrome P450-dependent monooxygenases and mitochondrial oxidative phosphorylation by fullerenol, a polyhydroxylated fullerene $\mathrm{C}_{60}$. Toxicol. Lett. 1997;93(1):29-37.

8. Meng X., Chen Z., Li B., Zhang Y., Zhao D., Yang $X$. Inhibition of $M-M u L V$ reverse transcriptase activity by fullerene derivatives. Chin. Sci. Bull. 2006;51(20):2550-2552.

9. Yang S.-T., Wang H., Guo L., Gao Y., Liu Y., Cao A. Interaction of fullerenol with lysozyme investigated by experimental and computational approaches. Nanotechnology. 2008;19(39):395101. 
10. Kotelnikova R. A., Smolina A. V., Grigoryev V. V., Faingold I. I., Mischenko D. V., Rybkin A. Yu., Poletayeva D. A., Vankin G. I., Zamoyskiy V. L., Voronov I. I., Troshin P. A., Kotelnikov A. I., Bachurin S. O. Influence of water-soluble derivatives of [60]fullerene on therapeutically important targets related to neurodegenerative diseases. Med. Chem. Comm. 2014;5(11):16641668.

11. Khakina E. A., Yurkova A. A., Peregudov A. S., Troyanov S. I., Trush V. V., Vovk A. I., Mumyatov A. V., Martynenko V. M., Balzarini J., Troshin P. A. Highly selective reactions of $\mathrm{C}_{60} \mathrm{C}_{16}$ with thiols from the synthesis of functionalized [60]fullerene derivatives. Chem. Commun. 2012;48(57):7158-7160.

12. Kobzar O. L., Trush V. V., Tanchuk V. Yu., Zhilenkov A. V., Troshin P. A., Vovk. A. I. Fullerene derivatives as a new class of inhibitors of protein tyrosine phosphatases. Bioorg. Med. Chem. Lett. 2014;24(14):3175-3179.

13. Kobzar O. L., Trush V. V., Tanchuk V. Yu., Voronov I. I., Peregudov A. S., Troshin P. A., Vovk A. I. Polycarboxylic fullerene derivatives as protein tyrosine phosphatase inhibitors. Mendeleev Commun. 2015;25:199-201.

14. Hendriks W. J., Elson A., Harroch S., Pulido R., Stoker A., Hertog J. Protein tyrosine phosphatases in health and disease. FEBS $J$. 2013;280(2):708-730.

15. Goldstein B. J., Bittner-KowalczykA., WhiteM.F., Harbeck M. Tyrosine dephosphorylation and deactivation of insulin receptor substrate-1 by protein-tyrosine phosphatase 1B. Possible facilitation by the formation of a ternary complex with the Grb2 adaptor protein. J. Biol. Chem. 2000;275(6):4283-4289.

16. Asante-Appiah E., Kennedy B. P. Protein tyrosine phosphatases: the quest for negative regulators of insulin action. Am. J. Physiol. Endocrinol. Metab. 2003;284(4):E663-E670.

17. Zabolotny J. M., Bence-Hanulec K. K., StrickerKongrad A., Haj F., Wang Y., Kim Y.-B., Elmquist J. K., Tartaglia L. A., Kahn B. B., Neel B. G. PTP1B regulates leptin signal transduction in vivo. Dev. Cell. 2002;2(4):489495.

18. Lessard L., Stuible M., Tremblay M. L. The two faces of PTP1B in cancer. Biochim. Biophys. Acta. 2010;1804(3):613-619.

19. Bialy L., Waldmann H. Inhibitors of protein tyrosine phosphatases: next-generation drugs?
Angew. Chem. Int. Ed. Engl. 2005;44(25):38143839.

20. Sayes C. M., Fortner J. D., Guo W., Lyon D., Boyd A. M., Ausman K. D., Tao Y. J., Sitharaman B., Wilson L. J., Hughes J. B., West J. L., Colvin V. L. The differential cytotoxicity of water-soluble fullerenes. Nano. Lett. 2004;4(10):1881-1887.

21. Isakovic A., Markovic Z., TodorovicMarkovic B., Nikolic N., Vranjes-Djuric S., Mirkovic M., Dramicanin M. Distinct cytotoxic mechanisms of pristine versus hydroxylated fullerene. Toxicol. Sci. 2006;91(1):173-183.

22. Mrdanovic J., Solajic S., Bogdanovic V., Stankov K., Bogdanovic G., Djordjevic A. Effects of fullerenol $\mathrm{C}_{60}(\mathrm{OH})_{24}$ on the frequency of micronuclei and chromosome aberrations in CHO-K1 cells. Mutat. Res. 2009;680(1-2):25-30.

23. Trott O., Olson A. J. AutoDock Vina: improving the speed and accuracy of docking with a new scoring function, efficient optimization and multithreading. J. Comput. Chem. 2010;31(2):455-461.

24. Rodriguez-Zavala J. G., Guirado-Lopez R. A. Structure and energetics of polyhydroxylated carbon fullerenes. Phys. Rev. B. 2004;69(7):075411.

25. Rodriguez-Zavala J. G., Guirado-Lopez R. A. Stability of highly OH-covered $\mathrm{C}_{60}$ fullerenes: role of coadsorbed $\mathrm{O}$ impurities and of the charge state of the cage in the formation of carbon-opened structures. J. Phys. Chem. A. 2006;110(30):9459-9468.

26. Hanwell M. D., Curtis D. E., Lonie D. C., Vandermeersch T., Zurek E., Hutchison G. R. Avogadro: an advanced semantic chemical editor, visualization, and analysis platform. J. Cheminform. 2012;4(1):17.

27. Coyuco J. C., Liu Y., Tan B. J., Chiu G. N. Functionalized carbon nanomaterials: exploring the interactions with Caco-2 cells for potential oral drug delivery. Int. J. Nanomedicine. 2011;6:2253-2263.

28. Brant J.A., Labille J., Robichaud C. O., Wiesner M. Fullerol cluster formation in aqueous solutions implications for environmental release. J. Colloid Interface Sci. 2007;314(1):281-288.

29. Nikolaev I. V., Lebedev V. T., Srushko Yu. S., Sedov V. P., Shilin V. A., Torok Gy., Melenevskaya E. Yu. Ordering of hydroxylated fullerenes in aqueous solutions. Fuller. Nanotub. Carbon Nanostruct. 2012;20(4-7):345-350. 
30. Cleland W. The kinetics of enzyme-catalyzed reactions with two or more substrates or products: II. Inhibition: nomenclature and theory. Biochim. Biophys. Acta. 1963;67:173-187.

31. Fromm H. J. Use of competitive inhibitors to study substrate binding order. Methods Enzymol. 1979;63:467-486.

32. Wiesmann C., Barr K. J., Kung J., Zhu J., Erlanson D. A., Shen W., Fahr B. J., Zhong M., Taylor L., Randal M., McDowell R. S., Hansen S. K. Allosteric inhibition of protein tyrosine phosphatase 1B. Nat. Struct. Mol. Biol. 2004;11(8):730-737.

33. Olmez E. O., Alakent B. Alpha7 helix plays an important role in the conformational stability of PTP1B. J. Biomol. Struct. Dyn. 2011;28(5):675693.

34. Kamerlin S. C. L., Rucker R., Boresch S. A targeted molecular dynamics study of WPD loop movement in PTP1B. Biochem. Biophys. Res. Commun. 2006;345(3):1161-1166.

Received 04.06.2015 